\title{
The Urgency of Pancasila Values as a Form of Millennial Generation Character Education
}

\author{
Gabriella Raisza Putri ${ }^{1}$, Moses Glorino Rumambo Pandin ${ }^{2}$ \\ ${ }^{1}$ Faculty of Psychology, Universitas Airlangga Surabaya \\ ${ }^{2}$ Faculty of Cultural Sciences, Universitas Airlangga Surabaya \\ 19abriella.raisza.putri-2020@psikologi.unair.ac.id, ${ }^{2}$ moses.glorino@ fib.unair.ac.id
}

\begin{abstract}
Background: Currently, Indonesia is entering an era that is all digital and uses technology in all fields of activity. The internet has a lot to do with their behavior or character. Millennials are the nation's next generation. The emergence of the digital era caused by globalization has made the millennial generation less appreciative and practicing the values of Pancasila. In this case, character education is something that must be applied to the millennial generation. Purpose: This study aims to analyze the characteristics of the millennial generation, the role of character education in realizing the values of Pancasila in the daily life of the millennial generation, how to cultivate an attitude of patriotism and nationalism towards the nation by practicing Pancasila, and provide motivation for the millennial generation to realize these values. Pancasila values. Methods: This study uses a literature review method. The search for journals was carried out using the google scholar database with the keywords "Character Education", "millennial generation", and "Pancasila". The journals selected are journals from 2019 to 2020. Results: By applying character education to the millennial generation, it will make it easier for them to practice the values of Pancasila. Pancasila should be the way of life of the millennial generation. Recommendation and limitation: As millennials, we must protect the country from values that are contrary to Pancasila. Character education must be applied following the nature of the millennial generation itself. Of course, the applied character education must prioritize and be based on the values of Pancasila as well.
\end{abstract}

Keywords: Character education; Pancasila; the millennial generation; digital era.

\section{INTRODUCTION}

Every activity carried out by the millennial generation today is never far away and is always related to technology. The millennial generation itself has nature to earn technology easily because of their ambitious nature and high obsession. The thing that makes them unable to stay away from technology is because they have a high individuality. The nature of individuality causes a decrease in the attitude of patriotism and nationalism towards the Indonesian nation. The millennial generation is required to face changes caused by the development of science and technology. Changes occur from various aspects, including economic, social, lifestyle, technology, and others. The millennial generation must be ready to 
face these changes if they do not want to be oppressed by the times. With the development of science and technology in this digital era, many possibilities can cause a moral decline in the millennial generation. The decline in morals and attitude in this generation cannot be avoided and is not realized. This is because foreign cultures enter Indonesia without any restrictions. External culture itself consists of good and bad culture. As a result, the Indonesian people themselves have to filter the culture. Of course, the millennial generation must filter it based on the values that exist in Pancasila. Good culture from foreign cultures is usually in the form of attitudes and morals, such as working hard, being on time, obeying existing rules, being patient in queues, and so on. The problem is that only a few of the millennial generation can filter out foreign cultures well.

In this digital era, Pancasila as the nation's view of life seems invisible to the millennial generation. Many problems that occur in this digital era are caused by the development of science and technology. An example is a crime that is rampant in cyberspace which is more dangerous than those in the real world. In addition, the problems that occur in the millennial generation are corruption, brawls between students, the damaged natural environment, promiscuity, violations of human rights, and so on. This shows the lack of morals and attitude that are embedded in this generation. In addition, this is also very contradictory to the values of Pancasila. In general, the causes of lack of morals in this millennial generation are abuse of gadgets, lack of parental supervision, and the influence of social media. To instill good values following Pancasila, the character is something that must be a concern for the millennial generation. Good and civilized characteristics of the millennial generation can lead the nation to become a good and civilized nation as well. This happens because the millennial generation is the generation that continues the life of the nation. The word character has the meaning of marking and focusing on how to apply the value of goodness in the form of action so that if the action is not following the value of goodness, it can be said to have a bad character (1).

Pancasila has a high position in the Indonesian state, namely the nation's personality, the source of identity, morality, and role models for the safety of the nation. Pancasila must be applied in various aspects of life to maintain the identity and personality of the nation. Thus, Pancasila can strengthen people's attitudes in dealing with foreign cultural values. Pancasila itself contains moral values and the cultural strength of the Indonesian nation. Character education has a connection with the values of Pancasila. If you have a bad character, you cannot practice the values of Pancasila in his life. The Indonesian millennial generation must have a 
high level of patriotism and nationalism. This can be realized by practicing the values of Pancasila when foreign cultures also enter Indonesia. Pancasila also helps a person to love his nation, so that the nature of patriotism and nationalism can grow.

The question that then arises is how can character education help the millennial generation in applying the values of Pancasila in this digital era? How to cultivate an attitude of nationalism and patriotism in the millennial generation who are surrounded by a very sophisticated world of science and technology? These questions will be answered further in this research which invites us to understand the characteristics of the millennial generation itself so that we know their point of view.

\section{METHOD}

The research method used is Literature Review. The literature review itself is part of the research that contains several references related to the research compiled. In this research method, the researcher identifies, evaluates, and conducts a synthesis analysis of the journals of a collection of research that has been collected according to the theme of Pancasila and the Millennial Generation. The purpose of choosing this method is because a field of study that has been studied previously can provide views from a study that has been studied previously. This research has gone through several stages. The first stage is to collect library materials in the form of journals according to the theme. Articles can be collected as many as possible according to the basic criteria for selecting a journal. The criteria are following the provisions of the theme, namely Pancasila and the Millennial Generation. In addition, the journals selected must include new journals, from 2019 to 2020 . The keywords in the selection of journal articles are character education, Pancasila, the millennial generation, and modern times. Then, the researcher selects the journals that will be used for reference articles to be made and the library materials that have been collected are read and studied. The next stage is to make important notes that become research material and group ideas so that views can become clearer. Then to proceed with processing important notes that have been made by the researcher. Then the last is to make conclusions from the material to be discussed (2).

The next technique that will be discussed is data analysis techniques. There are three data analysis techniques used in this study. First, inductive analysis is carried out by organizing and compiling matters related to the experience of the researcher according to the theme. The 
inductive analysis aims to make it easier for researchers to analyze data and be more concrete with the real life of researchers (2). Second, content analysis techniques are carried out by looking for the core to conclude an idea according to the theme. This makes it easier for researchers to draw up the conclusion section (2). Third, the descriptive-analytical technique is done by describing the data that has been found. This serves to answer the problems that will be discussed (2), namely how character education can help the millennial generation in applying Pancasila values in the digital era and how to grow the spirit of nationalism and patriotism in the millennial generation.

\section{RESULTS}

From all the references we analyzed, the basis of the state or the foundation of a nation will be strong if the people are strong depending on Pancasila which is the root of all national and state life in Indonesia. Pancasila must be a strong foundation for the nation affected by the development of science and technology, many Indonesian people have forgotten the values of Pancasila. They seem to think that foreign culture is better than the culture of their own country. Many of them even forget the precepts in Pancasila (3).

The people who can make Pancasila a strong foundation are the millennial generation. This can happen because the millennial generation is the next generation of the nation who will fight for the Indonesian nation. The millennial generation is a generation that is familiar with advanced technology and the modern world. They are the productive age generation. The millennial generation tends to like something instant because it is already surrounded by modern technology. They tend to not be away from gadgets, so they are more individualistic and have an indifferent nature to each other. It is undeniable that the millennial generation considers computers to be commonplace. They are more questioning his identity that looks unreal. This generation is not too concerned with the theory and prioritizes the results obtained. Many learning processes use the method of trial and error. They prefer learning that is similar to a game. This generation dislikes procrastination and is ambitious (4).

In this digital era, we have noticed that the millennial generation has not practiced the values of Pancasila in their lives. Many can be used as evidence that Pancasila values are not implemented in this digital era based on the precepts one to five. "Belief in One Supreme God" which is the first principle of Pancasila requires us to carry out our religious obligations. 
However, there are still many millennials who leave this obligation. In addition, in this digital era, many people blaspheme other religions through their social media. "Just and civilized humanity" as the second principle of Pancasila should be able to make society more united with the social community, not as a person. The millennial generation is more concerned with gadgets than the surrounding environment. The third precept which reads "Indonesian Unity" should be used as a guide to unite and make peace so that a strong nation can be realized. However, many millennials still insult each other and not respect each other. In this day and age, there are many demonstrations and riots in our environment. "Democracy led by wisdom in representative deliberation" which is the fourth precept of Pancasila is largely ignored by millennial society. Many of them do not respect other people's opinions when discussing and do not contribute at all to the discussion. The fifth precept "Social justice for all Indonesian people" is rarely seen. This is indicated by the fading attitude of cooperation, the creation of social differentiation, being picky in making friends, and so on (5).

Soekarno stated that independence is the result of character education to realize the personality of a sovereign nation in the political, economic, and cultural fields. With character education per precepts of the Pancasila, it can make it easier for the millennial generation to practice the values of Pancasila in their lives. With the practice of Pancasila values, over time a sense of nationalism and patriotism in millennial society will grow. In addition, this generation will prioritize the common interests rather than their interests (1).

Many obstacles can affect the improvement and development of character education. On internal factors, instincts can affect a person's character without any training and are unconscious. Furthermore, the habit factor becomes an internal factor that affects a person's character because usually a person's behavior is based on daily habits. Character formation cannot be formed instantly and requires a process. In addition to habits, character formation is influenced by the inheritance of traits in a blood bond. In addition, people with a strong desire will be motivated to achieve it. We can determine what kind of character we want as long as we have a strong will. Meanwhile, the external factors consist of promiscuity which greatly affects the millennial generation. In general, the millennial generation does not want to be left behind by the times and has high prestige, so they are easier to accept these cultures. In addition, the influence of body gadgets is also a problem because it can damage a person's life. If someone is addicted to gadgets, they will have bad characters, such as rebellion, emotional, dishonesty, and cannot use their time well (6). 
Pancasila has a deep meaning and animates the precepts of one another. Pancasila must be our foundation in acting and behaving. To make Pancasila the guide and foundation of our lives, the millennial generation needs character education. Character education is very important to apply the values of Pancasila because character education teaches us to practice good things and avoid bad behavior. The attitude of nationalism in this digital era can be realized with love for one's nation and respect for other nations. As a strong generation, millennial society accepts foreign culture, but still filters it with Pancasila values. That way, the millennial generation with good character can be realized and over time the nation's problems can be reduced and resolved.

\section{DISCUSSION}

Pancasila can be very useful if the whole community follows these precepts. But people's interest in Pancasila is very different. Some are not interested in Pancasila because the government does not implement it. Some are interested because of their philosophical needs and the values involved. However, several problems cause people to lack understanding and make them not interested in Pancasila. Some of the factors are rigid, heavy, too philosophical, and have many perceptions. In addition, Pancasila does not have a concrete example to make it easier for the message in Pancasila to be conveyed to the millennial generation. It is better if concrete examples are delivered continuously to suit the changing times because Pancasila has an adaptive nature and can be applied in an increasingly advanced era (7).

From the characteristics and current technological advances, the millennial generation must be able to respond to sophistication to access information wisely and proactively so that there is no decline in character values in society (8). The decline in morals and attitudes of today's society is due to a lack of character education when the development of technology and information occurs continuously. To be ready to face the development of science and technology, the millennial generation needs to improve and develop character education in carrying out their lives (9).

To overcome the above problems, the community can practice the values of Pancasila along with character education that can be applied based on local culture. This can make it easier for the millennial generation to become a strong next generation per Pancasila. Character education based on Pancasila can be applied with the principles of: take a positive new culture 
and maintain the old culture that is good for the life of the nation (10). Pancasila should not be changed completely because it is following the nation's personality.

Character education is something that must be done in this country's situation. To shape and change one's morals from negative to positive, character education is needed. At first, the origin of character education is the family environment, namely the cultivation of values, ethics, and morals that grow in a person. Family environment is important for character building. Then, after someone recognizes their environment, they will learn to socialize. The existence of encouragement and support from the surrounding environment greatly affects the strength of character in a person (11).

There are several ways to make character education effectively embedded in the millennial generation. First, the creation of a good atmosphere by parents must be created for their children to absorb character. The wrong parental upbringing can cause bad character in children. Parents must pay attention to their children, not fight in front of children, and have a good example for their children (1). The authority of parents in educating their children's character is also very influential. In this case, workshops and seminars on parenting can be used as an effort to provide knowledge about parenting patterns (12). The second way is to use a proactive, comprehensive, and deliberate approach to character development. This will facilitate the delivery of information to the millennial generation because they are more interested in simple things that are easy to understand. The third is to create a pleasant and caring atmosphere (13). Both in the school environment and the family environment, children are certainly more comfortable when they get attention (13). Fun learning that is delived optimally will motivate children (12). The fourth way is to provide opportunities for children to take moral actions. Moral actions in character education must be adapted to the values of Pancasila. For example, respecting the opinions of others, practicing worship, helping each other, and so on.

People can develop the character of nationalism and patriotism in many ways. First, build a character using a strong will to uphold moral values per precepts of the Pancasila and apply them in real life. The second way can be done by empowering characters, namely taking the initiative to build collective awareness by being an example for others with positive actions. The last way is to engineer character, which is to be actively involved in providing achievements based on their knowledge and culture and to be actively involved in the learning process (14). 
The more times develop the more challenges and problems that occur. However, by prioritizing character education, millennial society can become a useful society. A concrete example of this is the many millennials who excel, both at home and abroad. This can prevent the identity of the Indonesian nation from sinking and over time the Indonesian personality will be better known to the world. Indonesian cultures brought by the millennial generation at the international level also make the international community interested in visiting Indonesia.

\section{CONCLUSION}

Pancasila is a value that must be applied in the life of today's millennial society. The low understanding of Pancasila is increasingly diminishing the spirit of the millennial generation in implementing Pancasila. National characteristics can be developed by understanding the importance of Pancasila. In this digital era, the value of Pancasila needs to be increased because it is fading away. The millennial generation is the generation that will bring Indonesia into the future. If the people are strong and have solutions to every problem they have, then the country will also be strong. To anticipate problems caused by the development of science and technology and incoming foreign cultures, millennial communities must prepare themselves by making character education effective. By implementing character education based on Pancasila, the millennial generation will understand and be motivated to practice positive values by Pancasila. The application of Pancasila values can be started from small things. For example, loving each other, throwing garbage in its place, and respecting each other.

The millennial generation is a nation's asset. In this case, the character education delivered must be following the characteristics of the millennial generation so that the message is conveyed more easily. With the delivery of character education, the spirit of nationalism in them grows. If the millennial generation has a high spirit of patriotism and nationalism, then they can overcome challenges by providing appropriate solutions to state problems, especially in this digital era. In cultivating an attitude of nationalism, character education is needed as a shield for millennial society (14). Therefore, how to cultivate an attitude of nationalism and patriotism in the millennial generation who is surrounded by the world of science and technology must start from character education based on the values of Pancasila. As millennials, we must protect the country from values that are contrary to Pancasila. Pancasila 
does not need to be completely changed to be understood by millennials because Pancasila has an adaptive nature which is believed to be able to keep up with the times. Character education must be balanced with Pancasila education in educational institutions so that people understand and do not misinterpret the values in Pancasila. 


\section{Bibliography}

1. Hendayani M. Problematika Pengembangan Karakter Peserta Didik di Era 4.0. J Penelit Pendidik Islam. 2019;7(2):183.

2. Sonny Eli Zaluchu. Metode Penelitian di dalam Manuskrip Jurnal Ilmiah Keagamaan. J Teol Ber Hidup. 2021;3(2):6.

3. Wulandari S. Cara Pandang Pancasila dalam Generasi Milenial. J Fak Mat dan Ilmu Pengetah Alam. 2020;1-8.

4. Yuliyanti A, Marlianti C. Analisis Karakter Generasi Milenial dari Sudut pandang Buya Hamka. J Fak Ilmu Keislam. 2021;2(1):6.

5. Anggraini D, Fathari F, Anggara JW, Ardi Al Amin MD. Pengamalan Nilai-Nilai Pancasila Bagi Generasi Milenial. J Inov Ilmu Sos dan Polit. 2020;2(1):11.

6. Pendidikan U, Kampus I, Cibiru D, Guru P, Dasar S. Pemicu Lunturnya Nilai Pancasila Pada Generasi Milenial Devyanne Oktari, Dinie Anggraeni Dewi. J PEKAN. 2021;6(1):93-103.

7. Permatasari OS, Hanita M. Perspektif Generasi Milenial Terhadap Pancasila. J Huk dan Din Masy. 2021;19(1):6.

8. Fadilah N. Tantangan Dan Penguatan Ideologi Pancasila Dalam Menghadapi Era Revolusi Industri 4.0. J Digit Educ Commun Arts. 2019;2(02):66-78.

9. Hermino A, Arifin I. Contextual Character Education for Students In The Senior High School. Eur J Educ Res. 2020;9(3):1009-23.

10. Marsono. Pendidikan Karakter Berbasis Nilai Budaya di Era Milenial. Pros Semin Nas Dharma Acarya ke-1. 2019;51-8.

11. Latour B. Pendidikan Karakter. J Chem Inf Model. 2019;53(9):1689-99.

12. Asbari M, Nurhayati W, Purwanto A, Putra F. Pengaruh Genetic Personality dan Authoritative Parenting Style Terhadap Pendidikan Karakter di Aya Sophia Islamic School. Edumaspul - J Pendidik. 2020;4(1):142-55.

13. Istiyono E, Kartowagiran B, Retnawati H, Adi HC. Effective Teacher's Personality in Strengthening Character Education. Int J Eval Res Educ. 2021;10(2):512-21.

14. Ferry A. Eksistensi dan Peran Pancasila Dalam Menumbuhkan Rasa Nasionalisme dan Cinta Tanah Air Pada Generasi Milenial. Acad Edu. 2020;1-12. 